\title{
Kajian Ikonografis Senjata Tradisional Kurambiak Minangkabau Cakar Harimau Sumatera
}

\author{
Tedy Wiraseptya, Vernanda Em Afdhal \\ Universitas Putra Indonesia YPTK Padang \\ E-mail: tedyibob2@gmail.com, vernandaemafdhal@gmail.com
}

\begin{abstract}
Abstrak
Dalam pengkajian sebuah karya seni, kajian pertama yang dilakukan adalah kajian praikonografis. Kajian ini adalah kajian yang mengambil teori Erwin Panofsky, dimana kajian ini merupakan kajian primer yang melihat bentuk asli dari objek seni yang sifatnya faktual dan ekspresif. Di daerah Minangkabau salah satu senjata yang memiliki nilai sejarah ialah kurambiak /karambiak atau biasa disebut kerambit. Kurambiak memiliki banyak filosofi atau makna bagi masyarakat Minangkabau. Dimulai dari bentuk hingga pemakaian kurambiak yang masih dalam penelitian kualitatif dalam informasi dari kaba (kabar) oleh pemangku adat. Dalam penelitian ini penulis akan memakai suatu metode pengkajian tiga tahapan yang di kemukakan oleh Erwin Panofsky dalam bukunya "Meaning in The Visual Art". Tiga tahapan tersebut adalah PraIkonografis, konografi dan Ikonologi. Pada tahapan Pra-Ikonografis terbagi menjadi dua bagian yaitu elemen desain dan prinsip desain. Penelitian ini berfungsi untuk menjaga atau melestarikan warisan budaya Minangkabau dan menjadi acuan untuk membahas warisan benda seni secara visual.
\end{abstract}

Kata kunci: Ikonografi, Kurambiak, Minangkabau

\section{Pendahuluan}

Dalam proses pengkajian atas sebuah karya seni, butuh riset dan analisa Ikonografis. Proses Ikonografis adalah proses lanjutan dari teori Erwin Panofsky tahap berikutnya. Analisa ini berupa riset mendalam tentang karya seni yang mengungkapkan bagian dimensi-dimensi yang terkait. Hal ini juga mencakup tentang berbagai interprestasi imaji, cerita, serta kiasan.

Mengarah pada kata Erwin Panofsky, "Level makes sense of the first-level reading by way of hypotheses, generalizations, and interpretations". Jadi, Untuk menunjang pemahaman terhadap kurambiak Minangkabau secara lebih komperhensif, diperlukan kajian dari beberapa dimensi, diantaranya dimensi Teologis, Spritual, Filsafat, Etika, Historis, Antropologi Budaya, Psikologis, Sosiologis dan dimensi Estetika.

Senjata kurambiak memiliki nama yang berbeda setiap tempat seperti kerambit, kurambiak dan karambit. Dalam klasifikasinya senjata tajam paling berbahaya, kurambiak bisa dikatakan sebagai senjata mematikan menempati ukuran kedua setelah pistol. Ini karena, sebetan senjata kurambiak atau kerambit bila mengenai tubuh lawan, dari luar memang tampak seperti luka sayatan kecil, namun pada bagian dalam tubuh bisa menimbulkan akibat yang sangat fatal karena urat-urat putus. Dan apabila mengenai perut, maka harus terpotong atau tercabik-cabik didalam. 
Disamping menjadi senjata khas Minangkabau, permainan senjata kerambit juga berkembang di Madiun Jawa Timur yang dalam aksen Jawa disebut dengan nama "kerambik". Permainan senjata ini diajarkan oleh Ki Ngabei Surodiwiryo dalam permainan pencak silat Setia Hati (SH), yang didapatnya dari Gurunya yang bernama Datuk Rajo Batuah di Kampung Ampang Padang. Dan Datuk Rajo Batuah tersebut merupakan murid dari para Panglima Minangkabau yang disebut Harimau Nan Salapan. Di Madiun, permainan senjata kurambiak atau kerambit ini menjadi senjata khas pencak silat Setia Hati.

Berdasarkan sejarah tertulis, kurambiak atau kerambit berasal dari Minangkabau, lalu kemudian dibawa oleh para perantau Minangkabau berabad yang lalu dan menyebar ke berbagai wilayah, seperti Jawa, Semenanjung Melayu dan lain-lain. Menurut cerita rakyat, bentuk kurambiak terinspirasi oleh cakar harimau yang memang banyak berkeliaran di hutan Sumatera pada masa itu.

Kurambiak, sengaja dirancang lebih melengkung seperti kuku harimau, setelah melihat harimau bertarung dengan menggunakan cakarnya, hal ini sejalan dengan falsafah Minangkabau yang berbunyi Alam takambang jadi guru. Dimana ada banyak filsafah tua Minangkabau yang melekat pada senjata tradisional Minangkabau tersebut.

Pada masa dahulu, permainan senjata kurambiak di Minangkabau hanya diwarisi oleh para Datuk atau kalangan Raja, tidak sembarang orang menguasai permainan yang dianggap rahasia dan hanya untuk kalangan tertentu saja.

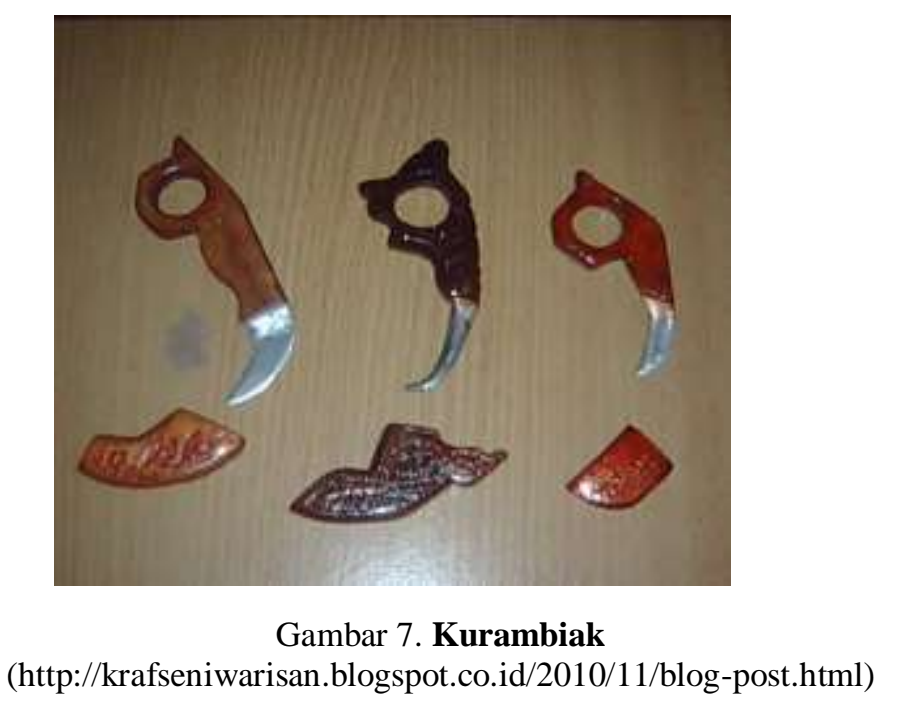

Senjata khas Minangkabau ini menjadi bagian terpenting yang tak dapat dipisahkan dari silat Minangkabau (silat Taralak). Keistimewaannya seperti kuku harimau (Minangkabau: inyiak) yang setiap saat secara tiba-tiba keluar dari balik kaki dan tangannya pada saat menerkam atau memangsa lawan. Untuk itu harimau menjadi perlambang satria-satria atau Panglima Minangkabau.

Dimainkan dengan sistem langkah silat Taralak, senjata ini bagaikan tanduk kerbau dan semangat bertarungnya seperti kerbau. Dalam riwayat Minangkabau, kerbau kecil orang Minang dapat mengalahkan kerbau besar milik Raja Jawa. Kerbau juga menjadi perlambang suku bangsa Minangkabau. Dalam pepatah Minangkabau dikatakan 
bahwa jika seorang pendekar atau satria belum menguasai kurambiak, ibarat harimau tanpa kuku, ayam tanpa tajinya, burung tanpa paruhnya, gajah tanpa gadingnya, kerbau tanpa tanduknya.

\section{Teori}

Sepasang kurambiak bila dimainkan, menggambarkan seekor kerbau yang menjadi lambang suku bangsa Minangkabau. Hal ini mengisyaratkan jati diri seorang satria atau pendekar Minangkabau yang sebenarnya. Dalam memainkan langkah kurambiak, kurambiak muncul dari sisi atau samping perut, tersembunyi disamping iga atau rusuk. Hal ini mengandung maksud:

“ Kerambit ibarat tulang iga (bentuknya melengkung), mengingatkan kepada riwayat seorang wanita, sehingga wajib hukumnya untuk menempatkan wanita pada kedudukan yang terhormat mengingat kedudukannya sebagai seorang ibu. Dalam sistem adat Minangkabau, wanita memperoleh kedudukan yang sangat tinggi (matrilineal)."

“ Kerambit ibarat tulang rusuk, memperlihatkan bahwa organ-organ tubuh bagian dalam manusia terlindungi oleh rusuk yang dapat membentuk tubuh manusia memiliki alat pertahanan yang kokoh dan kuat. Jika tidak ada tulang rusuk, maka badan menjadi lemah. Rusuk berfungsi melindungi ancaman dari luar dan ancaman dari dalam agar organ bagian dalam tidak mudah keluar dari badan. Dibalik rusuk juga bersemayam hati atau sumber rasa".

Dapat disimpulkan bahwa sebenarnya senjata kerambit itu adalah senjata yang berasal dari dalam tubuh manusia. Maka dalam pencak silat Minangkabau atau pencak silat Setia Hati (disingkat $\mathrm{SH}$ ) merupakan satu kesatuan sistem yang tak dapat dipisahkan. Senjata yang ampuh adalah senjata yang berasal dari dalam diri manusia itu sendiri. Seperti yang digambarkan pada binatang kerbau yang memiliki tanduk yang kuat dan harimau yang memiliki kuku yang tajam, senjatanya binatang juga berasal dari dalam dirinya sendiri.

Buku sejarah di Eropa mengatakan bahwa tentara di Indonesia dipersenjatai dengan keris di pinggang dan tombak di tangan mereka, sedangkan kerambit itu digunakan sebagai upaya terakhir ketika senjata lain habis atau hilang dalam pertempuran. Kerambit terlihat sangat jantan, sebab ia dipakai dalam pertarungan jarak pendek yang lebih mengandalkan keberanian dan keahlian bela diri. Para pendekar silat Minang, terutama yang beraliran silat harimau sangat mahir menggunakan senjata ini. Saat ini kerambit adalah salah satu senjata utama silat dan umumnya digunakan dalam seni beladiri.

Cara penggunaan kurambit, senjata dipegang dengan memasukkan jari pertama atau telunjuk ke dalam lubang di bagian atas pegangan sehingga lengkungan pisau mengarah ke depan dari bagian bawah kepalan tangan. Hal ini terutama digunakan dalam pemotongan dengan cara memutar tangan ketika kerambit telah masuk atau mengenai sasaran, sehingga bagian dalam dari sasaran, seperti urat, usus dan lainnya menjadi putus. Luka akibat kerambit terlihat kecil dari luar, namun didalamnya, urat atau usus telah putus. Dengan masuknya jari telunjuk ke dalam lobang gagang kerambit, membuat lawan sulit untuk melucuti senjata tersebut dan memungkinkan kerambit untuk bermanuver di jari-jari tanpa kehilangan pegangan. 
Menjadi sempurna jika dimainkan sepasang dengan 2 tangan posisi atas dan bawah secara bergantian kiri dan kanan. Maksudnya untuk menutup semua celah yang memungkinkan untuk bisa ditembus lawan. Sehingga dengan memainkan sepasang kerambit menjadi sebuah pertahanan yang sangat rapat dan kokoh yang sulit untuk ditembus atau dimasuki oleh serangan lawan yang bagaimanapun hebatnya.

Dimainkan khusus untuk pertarungan jarak dekat atau rapat. Setelah ujung kerambit berhasil menembus tubuh lawan, dengan seketika harus dibalikkan atau diputar arah. Hasilnya akan tampak diluar seperti luka dengan robek kecil tetapi di bagian dalam organ-organ tubuh putus. Apabila menyangkut ditangan lawan, akibatnya akan sangat mengerikan yakni semua urat tangan putus terkelupas bahkan tangan bisa potong.

Permainan senjata kerambit ini akan sangat ideal jika dimainkan dengan permainan silat Taralak (di pencak Setia Hati disebut Sterlak). Taralak dalam bahasa Minangkabau berarti "kabau", sebuah langkah silat tanpa mengenal mundur, seperti langkah kerbau yang selalu merangsek maju dengan kedua tanduknya, hanya mengenal istilah hidup atau mati. Untuk melihat akibat dari keganasan senjata ini, bisa kita lihat di Youtube dalam bentuk video, sungguh sangat mengerikan.

\section{Metodologi}

Dalam metode ikonografi dari Erwin Panofsky diperlukan kajian pra-ikonografi sebagai Aspek-aspek tampak pada bentuk ini meliputi berbagai unsur, yaitu;

\section{A. Titik}

Unsur seni rupa yang paling dasar yang berada pada dimensi satu. Dibutuhkan adanya titik untuk membentuk garis, bentuk, ataupun bidang. Titik sebagai unsur terkecil dan dasar dari sebuah karya visual. Titik adalah unsur yang sangat berperan penting dalam menyatakan bentuk kurambiak ini. Pada setiap tekstur di beberapa kurambiak juga punya unsur estetis yang terukir pada setiap sudutnya. Pada pola sarang/sarung dari senjata minang ini terdapat ukiran-ukiran dari tinta emas. Garis-garis itu berawal dari titik-titik yang di gabungkan menjadi garis.

\section{B. Garis}

Garis adalah unsur seni rupa yang merupakan hasil dari penggabungan unsur titik. Garis dalam seni rupa menjadi goresan atau batasan dari suatu benda, ruang, bidang, warna, tekstur dan lainnya.

Garis terbagi atas tiga, yaitu ;

1). Garis menurut jenisnya, garis menurut jenisnya adalah garis lengkung, garis panjang, garis pendek, garis horizontal, garis vertikal, garis diagonal, garis berombak, garis putus-putus, garis spiral dan lainnya.

2). Garis menurut kesannya, garis menurut kesannya dapat ditimbulkan oleh adanya variasi jenis-jenis garis yang digunakan serta kebudayaan yang ada saat tersebut, terhadap suatu simbol.

3). Garis menurut wujudnya, garis yang berasal dari wujudnya

Pada kurambiak garis memiliki lengkungan hampir dari sembilan puluh derjat. 
Membentuk seperti kuku yang di ambil dahulu dari bentuk kuku harimau Sumatera. Teori ini sudah lama berkembang pesat semenjak zaman belanda menyerang dahulu, karna binatang yang ditakuti saat itu adalah harimau sumatera.

\section{Bentuk}

Pada aspek bentuk Kurambiak ini berbentuk pisau, bermata satu, pola ini lebih tepatnya seperti kuku harimau, melengkung, dengan mata pisau di dalam. Gagang terbuat dari kayu dan beberapa kurambiak dihias menurut filosofi yang berkembang di adat budaya Minangkabau. Pada bagian gagang Kurambiak ini ada sebuah bolongan yang dipakai untuk menambah kekuatan pegangan.

\section{Warna}

Pada kurambiak Minangkabau hanya berwarna di bagian gagang/pegangan saja. Disisi gagang yang berwarna pun juga hanya dua warna yang terbalut pada kurambiak. Pertama warna kayu yang memang warna asli dari kayu dan kedua warna hitam yang disamakan dengan warna mata pisau.

\section{E. Tekstur}

Kurambiak ini merupakan senjata yang dibuat dari besi, baja, batu meteor dan kayu. Pada gagang terkadang para pemilik Kurambiak memberikan motif-motif Minangkabau (filsafat).

Dalam pembuatan Desain, perlu adanya penyusunan, komposisi atau pengorganisasian unsur desain. Prinsip desain saling terkait antara satu dengan yang lainnnya. Dengan prinsip desain yang dikemukakan Erwin Panofsky, maka pada Kurambiak ini dapat dijabarkan sebagai berikut :

\section{A. Ukuran}

Kurambiak yang berasal dari Minangkabau biasanya berukuran 5 x 8 centimeter atau yang paling kecil ukuran 5 x 5,5 meter.

B. Skala

Berpatokan pada ukuran skala pisau dapur bisa dibilang kurambiak kecil, hanya segenggam tangan manusia dewasa.

\section{Harmoni}

Harmoni yang diperlihatkan pada kurambiak Minang adalah harmoni keanekaragaman dan budaya.

\section{Keseimbangan}

Kurambiak ini memiliki pegangan yang seimbang. Terlihat dari bagian pangkal yang besar dan ringan sekalius berusaha menyeimbangkan beban pisau.

E. Irama

Kurambiak memiliki garis ukiran yg nampak seperti bunga. Mengikuti adat yanng berlaku. Garis garis itu terukir berkesinambungan menambah emotional para pemakai.

F. Penekanan

Setiap benda seni pasti memiliki penekanan masing-masing. Kurambiak ini menonjolkan tekanan pada pola bentuk. Bisa dilihat dari betnuk yang berbeda dari senjata tajam lainya.

G. Pola dan Ornament

Pola kurambiak ini sangat kental berbentuk seperti cakaran harimau. Penampilan kurambiak pun berbeda-beda walau masih dalam bentuk yang sama. 
1). Pola Pituah Adat: Dibagian sarang/sarung-nya dibetuk ornament klasik adat. Begitupun dibagian pisaunya, ada ornament "Kaluak Paku" (Filsafah kehidupan minang) menghiasi.

2). Pola Geomentris : Tampak pada pola garis lengkung dibagian besi pisau dibuat gradasi tebal setengah centimeter sampai tipis (tajam).

Kajian pra-ikonografi melihat sisi luar dari sebuah benda seni yang menghasilkan tampilan visual dari bentuk, tekstur dan ornamen. Kajian pra-ikonografi adalah kajian dasar untuk kajian ikonografi yang melihat sisi, makna dan filosofi dari sebuah kajian seni. Pada dasarnya setiap benda memiliki dimensi tersendiri sesuai penggunaan dan penerapannya pada masyarakat. Untuk melihat kajian tersebut kajian ikonografi pada kerambit dibedah dalam dimensi teologis, dimensi filsafat, dimensi antropologi budaya dan dimensi estetika.

\section{A. Dimensi Teologis}

Dilihat dalam dimensi teologis bahwa dibalik segala kehidupan yang di jalani di dunia ada satu hal yang mempunyai kekuatan stabil, dibandingkan kekuatan sendiri. Science, Teknologi, Art tidak akan mampu menyeimbangkannya. Manusia sadar akan kekuatan itu adalah ketuhanan.

Al-Qur'an adalah kitab Allah yang diturunkan kepada Nabi Muhammad saw sebagai petunjuk bagi umatnya. Di dalamnya terdapat ayat-ayat yang jelas bagi manusia yang mau menggunakan akal - fikirannyanya. Al-Qur'an tidak meninggalkan sesuatu yang kecil apalagi yang besar kecuali mencatatnya. Tidak ada satupun perkara/sesuatu baru yang diperbuat manusia, maka demikian pula ilmu pengetahuan manusia kecuali pasti ada dalilnya di dalam Al-Qur'an. (Jamaluddin, Mubasyir, 2006: 35).

Setiap Agama mempunyai kitab yang masing-masing menjadi pegangan bagi umatnya. Dalam kitab ada petunjuk bagi orang-orang yang percaya dan mengimaninya. Maka dari sana kita menarik sebuah kesimpulan, bahwa setiap agama memiliki kesamaan. Hal yang sama itu adalah aturan dan ajaran yang baik. Tidak satupun agama yang meluruskan perkara tentang keburukan.

Benda seni merupakan hal yang berhubungan dengan hati dan perasaan. Karna seni menanamkan emotional jiwa dan diciptakan untuk mencapai tujuan yang dipergunakan untuk kebajikan.

Kurambiak, Benda seni yang erat kaitannya dengan agama. Sepasang Kerambit bila disatukan, menggambarkan perlambang hati. Dan barangsiapa yang setia kepada hati sanubarinya atau dapat merasakan sumber dari rasa yang selalu menghadap kepada Tuhan, niscaya ia akan selamat lahir bathinnya dan sampai kepada tujuannya. Artinya mengandung nilai ketaqwaan. Namun, jika ingkar atau menyimpang dari hati sanubarinya, maka ia akan celaka karena perbuatannya itu. Hal ini digambarkan dari senjata Kerambit yang tajam sisi luar maupun sisi dalamnya, dari luar mampu melindungi ancaman dan dari dalam juga dapat memberi kontrol diri karena jika menyimpang akan menjadi senjata makan tuan. Dengan demikian untuk meraih kemenangan atau tujuan, maka dalam memainkan senjata Kerambit juga harus berpedoman pada hukumnya yakni menjalankan "langkah" dalam "jurus" yang benar, tidak asal melangkah dalam memainkan suatu jurus.

Karna itu, dahulu kerambit hanya para datuak ${ }^{6}$ dan hanya berjiwa besar (dewasa) yang bisa memilikinya. Karna kurambiak/kerambik juga sebagai lambang kedewasaan kita menyikapi sesuatu. 


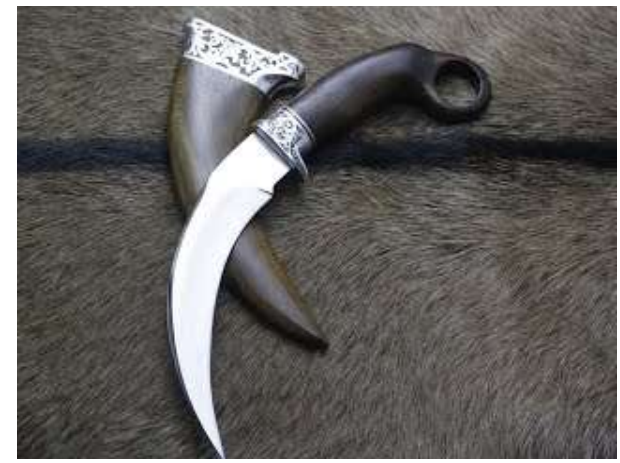

Gambar 2

Kurambiak Minang

(https://sites.google.com/a/ce.undip.ac.id/senjata-tradisional/home/sumatera-barat)

\section{B. Dimensi Filsafat}

Filsafat pada era Yunani kuno adalah induknya ilmu. Jika kita menggali lagi tentang filsafat maka Filsafat adalah pandangan hidup seseorang atau sekelompok orang yang merupakan konsep dasar mengenai kehidupan yang dicita-citakan. Filsafat juga diartikan sebagai suatu sikap seseorang yang sadar dan dewasa dalam memikirkan segala sesuatu secara mendalam dan ingin melihat dari segi yang luas dan menyeluruh dengan segala hubungan. Menurut Harun nasution filsafat adalah berfikir menurut tata tertib (logika) dengan bebas (tak terikat tradisi, dogma atau agama) dan dengan sedalamdalamnya sehingga sampai ke dasar-dasar persoalan. Jika mengerucut pada Kurambiak, maka kita akan menemukan suatu hal yang lahir dari teori Lyotard tentang istilah 'Posmodren'. Walau pada hakekatnya cara ini jauh di bilang melawan ketentuan publik. Tapi, lahirnya istilah posmodren ini bisa menjadi acuan bagi kita dalam kurambiak. Jika kita telusuri dari dalam tentang perjalanan kurambiak di Minangkabau, maka akan ditemukan bahwa Kurambiak tidak lebih hanya sekedar untuk memotong rumput, padi dan ilalang. Perkembangan kurambiak dan kegiatan masyarakat menjadikan kurambiak sebuah alat senjata bagi masyarakat Minangkabau. Seperti yang ditemukan pada Asian Journal British, July - Dec 1827, tentang penggunaan kurambiak. Jika dilihat bentuk, pisau genggam kecil berbentuk melengkung. Senjata ini termasuk senjata yang sangat bebahaya, karna dapat digunakan menyayat maupun merobek anggota tubuh lawan secara cepat dan tidak terdeteksi.

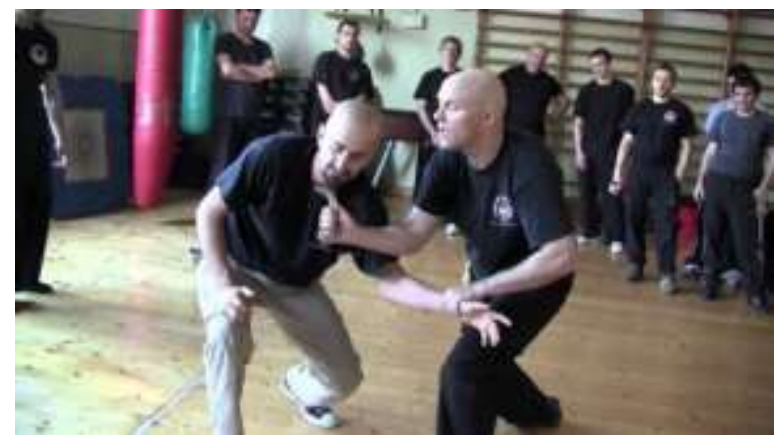

Gambar 3. Kerambit di Luar Negri

(http://forum.liputan6.com/t/kerambit-senjata-asal-minangkabau-sumatera-barat-yangmendunia/61942) 


\section{Dimensi Antropologi Budaya}

Definisi Antropologi menurut Carol R. Ember and Melvin Ember dalam buku Antropology, "Is a discipline of infinite curiosity about human being. The term comes from the Greek 'anthropo's for "man, human" and logos for "study". Anthropologist seek answer to an enormous variety of question about humans. They are interest in discovering when, where and why human on the earth,... “

Pada perkembangannya, pendekatan filosofis atas kebudayaan terkritik untuk digerakkan oleh perspektif fungsional yang kemudian tergeret dalam diskursus strategi kebudayaan. Kritik ini mengemuka pada pergeseran dari "apa" kebudayaan, menjadi "bagaimana" kebudayaan memberikan manfaat bagi masa depan manusia, terkhusus dalam kerangka lestarinya kebudayaan itu sendiri.

Jika kebudayaan adalah sebuah nilai, maka pada sistem nilai inilah kebudayaan sebagai sistem pengetahuan dan makna, dapat menjelma sebagai sistem tingkah laku, perbuatan dan tindakan. Dari sini etika dan moral kemudian menjadi titik kritis dan menentukan apakah suatu sistem budaya (cultural system) yang terdiri dari perangkat makna dan perangkat nilai dapat diterjemahkan menjadi social system, berupa perangkat tindakan, perbuatan dan tingkah laku.

Adanya silat Minangkabau atau silek Minangkabau yang dimiliki oleh masyarakat itu adalah tradisi yang diturunkan turun menurun. Hal itu dilakukan atas dasar masyarakat Minangkabau memiliki tabiat suka merantau semenjak beratus-ratus tahun yang lampau. Untuk merantau, tentunya mereka harus punya bekal yang cukup dalam menjaga diri dari hal-hal terburuk selama di perjalanan atau dirantau, misalnya diserang atau dirampok orang. Disamping sebagai bekal untuk merantau.

Dalam dunia beladiri tentu adanya pegangan (senjata) untuk berjaga-jaga. Jadi secara fungsi kebutuhan kurambiak sama dengan silat, diantaranya :

a. Panjago diri

Pembelaan diri dari serangan musuh

b. Parik paga dalam nagari

Sistem pertahanan negeri

Untuk dua alasan inilah masyarakat Minangkabau pada tempo dahulunya perlu memiliki sistem pertahanan yang baik untuk mempertahankan diri dan negerinya dari ancaman musuh kapan saja. Orang yang lihat beladiri/silek disebut 'Pandeka', diambil dari kata-kata pendekar.

\section{Dimensi Estetika}

Estetika berasal dari kata Yunani "Aesthesis", yang berarti perasaan atau sensivitas. Oleh karena segala yang dapat dirasakan oleh manusia diterima melalui indera, dapat dikatakan bahwa estetika merupakan segala sesuatu yang ditangkap oleh indera manusia baik itu indah maupun tidak. Kurambiak adalah peniggalan leluhur yang masih bisa kita nikmati sampai sekarang. Adapun yang meliputi keindahan dalam segi bentuk itu karna paduan dimensi yang berkembang sampai sekarang. Ia secara asimilasi berbaur pada lingkungan dan berubah sesuai zaman tanpa kita bisa melupakan dasar Kurambiak adalah dari Minang. 
Dalam filosofi minang “dima bumi dipijak disitu langit dijunjuang”. Dimana kita berada disanalah kita berusaha untuk bisa berbuat baik dengan orang lain. Hal ini juga menggingatkan kita bahwa kurambiak adalah simbol estetika yang mampu menggiring kita pada pesan moral di negri Minangkabau. Dalam setiap lekukan yang elok dipandang itu ada muncul ketegasan. Bukan hanya ketegasan idealis tapi ada pandangan subjektif terhadap kemampuan diri untuk selalu mengendalikan diri. Beberapa Motif yang lahir dan di adaptasi pada bilah kurambiak "Kaluak Paku", mengisaratkan pada kehidupan yang harus berjuang tanpa henti. Selalu mengingat yang bana (benar). Kurambiak menyimpan beribu makna dan sejarah. Karna Minangkabau tidak pernah mempunyai buku sejarah atau prasasti yang menulis kegiatan masa lampau

\section{Hasil}

Kurambiak atau kerambit adalah sebuah benda seni dengan keberfungsian sebagai senjata. Pada pra-ikonografi unsur titik, garis, pola, ornamen dan tekstur menjadikan kurambiak mempunyai nilai kearifan lokal yang terinspirasi dari kuku harimau dengan pola ornamen kehidupan masyarakat Minangkabau. Pada kajian ikonografi tersirat bahwa dimensi antropologi budaya menyambungkan antara kurambiak dan silat Minangkabau. Begitupun dimensi estetika juga memperlihatkan sisi keindahan Minangkabau dengan motif yang terukir pada setiap bentuknya.

\section{Kesimpulan}

Pada dasarnya setiap benda seni mempunyai nilai-nilai budaya lokal yang mampu digali sehingga dapat dilaksanakan penelitian yang seharusnya menjadi tolak ukur dan upaya untuk melestarikan ataupun mengangkat sebuah nilai-nilai kebudayaan ke permukaan. Dari kajian kurambiak yang dibedah melalui pisau bedah Erwin Panofsky berhasil dikaji bahwa dari benda seni kecil banyak makna dan arti yang terkandung didalamnya, yang mengungkapkan bahwa telah ada sebuah peradaban yang dilihat secara tersurat maupun tersirat didalam sebuah benda seni. Mudah-mudahan pengkajian ini menjadi titik balik ataupun pelacut untuk lebih peduli dan mengeksplorasi kearifan lokal lainnya.

\section{Daftar Pustaka}

[1] A Navis A. Layar Terkembang Jadi Guru : Adat Kebudayaan Minangkabau. Jakarta : Pt. Grafiti Pers.Kusrianto, Adi. 2007. Pengantar Desain Komunikasi Visual. Yogyakarta: CV. Andi Offset.

[2] Bakthiar, Amsal. 2012. Filsafat Ilmu. Jakarta : Pt. Raja Grafindo Persada.

[3] Ember, Carol R., Melvin Ember. 1996. Anthropology Eighth Edition. New Jersey : Prentice Hall.Maran, Rafael Raga. 2010. Manusia \& Kebudayaan Dalam Perspektif Ilmu Budaya Dasar. Jakarta: Rineka Cipta.

[4] Frow, John. 1995. Cultural Studies And Cultural Value. Oxford : Clarendon Press.

[5] Herusatoto Budiono. 1948. Simbolisme dalam Budaya Jawa. Yogyakarta : PT Hanindita.

[6] Jamaludin, Mubasyir. 2006. Al-quran Bertutur tentang Makanan dan Obat-obatan. Yogyakarta : Mitra Pustaka.

[7] Kartodirjo, Sartono. 1990. Ungkapan-Ungkapan Filsafat Sejarah Barat dan Timur, Jakarta : Gramedia.

[8] Panowfsky, Erwin. 1955. Meaning inThe Visual Art. NY : Doubleday \& Company, Inc.

[9] Praja, Juhaya S. 2008. Aliran-aliran Filsafat \& Etika. Jakarta : Kencana.

[10] Russell, Bertrand. 2002. Sejarah Filsafat Barat Kaitannya dengan Kondisi Sosio-Politik Zaman Kuno hingga Sekarang. Yogyakarta.

[11] Sumardjo, Jacob. 2000. Filsafat Seni. Bandung : ITB.

[12] Yusuf Lubis, Akhyar. 2014. Teori dan Metodologi. Jakarta. 